\title{
Anti-Corruption Protection of Russian Companies in Foreign Jurisdictions
}

\author{
Victor V. Astanin* \\ Bank of Russia \\ Moscow, Russian Federation
}

Received 27.12.2019, received in revised form 15.01.2020, accepted 20.01.2020

\begin{abstract}
The article is devoted to existing problems and prospective tasks of preventing corruption risks and fraudulent threats that domestic public organizations conducting foreign economic activity in the countries of their presence may encounter. The globalization of anti-corruption standards of business conduct rules imposed on business structures around the world is due to the cross-border nature of the laws of several states of the Anglo-Saxon legal system, as well as the OECD Convention on Combating Bribery of Foreign Public Officials in International Business Transactions. These circumstances require the actualization of the tasks of the anti-corruption policy of every public company, regardless of the country of its affiliation, legal form and type of ownership. Most business organizations in the world are developing their own tactical preventive measures against corruption abroad. The content of these measures is different. In the absence of a unity of approaches to organizational, methodological, regulatory support, as well as legal regulation and application of such measures, the article presents the results of monitoring national and multinational companies' practices aimed at prevention of corruption risks that may arise in interaction with foreign contractors. The monitoring results are proposed to be considered in the methodological positions of the prospective development of a unified strategy for the prevention of corruption risks for domestic companies operating abroad.
\end{abstract}

Keywords: corruption, prevent, foreign economic activity, Due Diligence, companies, internal control and audit, Anglo-Saxon law, business, ethical dilemmas.

Research area: law.

Citation: Astanin, V.V. (2020). Anti-corruption protection of russian companies in foreign jurisdictions J. Sib. Fed. Univ. Humanit. Soc. Sci., 13 (1), 6-12. DOI: 10.17516/1997-1370-0546

(C) Siberian Federal University. All rights reserved

* Corresponding author E-mail address: astaninvv@rambler.ru 


\section{Introduction}

Foreign economic activity (either import/ export of goods, works, or services), which is represented by the participants of business relations, shall be conducted in compliance with the national legislation. In case of entrepreneurial legal relations, it is not difficult to meet these requirements due to the analogy with foreign regulations of the civil law. Eventually, business relations are created in accordance with the terms and conditions of a contract made between the parties and mutual compliance with the requirements of the countries they represent. However, in case of specific national approaches to the legal regulation of business transactions at the state level, the issues of their protection against corruption require special attention.

The issues of legal liability of companies for bribing officials, including foreign ones, are of primary importance. In different states they are solved differently. In the Russian Federation, the liability for such bribery is provided in the administrative legislation by the Article 19.29 of the Code of Administrative Offences of the Russian Federation - "An Improper Inducement on Behalf of a Legal Entity". Disposition of the aforementioned regulation includes the fact of giving, offering, or promising money, securities, or property, as well as providing property-related services, granting property rights for or on behalf of a legal entity to an official of a commercial/another organization for an action (or an omission to act) for the benefit of this legal entity.

Legal liability for corruption, with legal entities involved in it, is widely imposed in some continental law countries (France, Italy, Germany, the Netherlands). In the countries of the Anglo-Saxon legal system (the USA, Great Britain, Canada, Australia), as well as in the states implementing their regulations (Brazil, South Korea) apart from criminal liability of legal entities, there is also their civil liability providing for reinstitution imposed in order to restore a loss incurred as a result of a business transaction involving corruption.

In Southeast Asian states (Japan, South Korea, Singapore, a part of the P.R. China) mainly ethical dilemmas of companies, stan- dards of their employees' due care (for example, referring to receiving gifts, providing services (paying for entertainments, holiday)), complying with the principles of cooperation with representatives of other organizations serve the purpose of corruption prevention within legal entities.

Analysis of the anti-corruption foreign legislation is relevant for the Russian companies, which plan to or operate under another jurisdiction, especially in countries with a mixed legal system. Russian organizations (legal entities) and their employees (individuals) can be subject to the regulations and sanctions, provided by the legislation of the states where they operate or their contractor is registered. It is necessary for many companies to comply with foreign anti-corruption regulations, both legislative and corporate ones.

\section{Theoretical framework}

Companies operating under foreign jurisdictions need to comply with anti-corruption standards and rules due to the validity of international legal documents all over the world and the policy, which supports them. It covers all individuals and legal entities, regardless of their legal form, administrative and territorial affiliation, tax regime, sphere of activity, beneficiaries, members, etc.

Such trends are set by the Convention on Combating Bribery of Foreign Public Officials in International Business Transactions (hereinafter - the OECD Convention). There are 43 OECD Convention member states that actively participate in the world economy and trade. Under the OECD Convention, criminal prosecution of the subject of bribery is of extraterritorial nature, regardless of the location or jurisdiction affiliation. In 2012, the Russian Federation ratified the OECD Convention accepting its principles and undertaking obligations to unexceptionally comply with all its provisions. Its basic regulations provide the following:

1) punishability of a promise and an offer of any illegal rewards, benefits, services, rights on behalf of a company to foreign officials in order to get or retain its commercial advantage, referring to its business operation; 
2) punishability of tax refunds from corrupt payments (when a company applies to fiscal authorities in order to refund money spent on bribing after making a corrupt transaction);

3) expanded interpretation of a bribe with nonmonetary benefits (holiday, entertainments, medical treatment), which is at the law enforcer's discretion.

The global reach of exclusive force of some foreign anti-corruption laws that provide for prosecution for acts of corruption, involving (even passively) foreign organizations and their employees, should not go unmentioned. It refers to the Foreign Corrupt Practices Act, 1977 - FCPA and the UK Bribery Act 2010. At present foreign companies have to comply with the provisions of the latter, even if they are not physically present or do not operate in Great Britain.

Particularly, the UK Bribery Act 2010 provides for criminal liability of any organizations, doing business, for not taking any measures to prevent giving or receiving a bribe by associated legal entities. It does not provide for the definition of "An associated entity", and this term is interpreted pursuant to case law. Thus, it is realistic to hold an organization, which has not prevented a bribery committed by its contractor (dealer, partner, agent, distributor, supplier, customer) within the scope of its own relations with third-party companies, if they are British, do business with British companies, or even if they use pounds - the official currency of Great Britain - in their financial arrangements, liable. It should be emphasized here that the UK Bribery Act 2010 does not stipulate a mechanism of establishing the guilt of the organization for acts of corruption committed by its contractor. However, it provides that if a company has adequate procedures for corruption prevention, this fact serves as the grounds for exclusion of liability should its associated company (representative) commit bribery. The definition of "Adequate procedures", which would enable to exclude charges with connivance in corruption or to prove company's zero tolerance to bribery, is not provided. Pursuant to the general rule, this must be ensured by harmonization of the company's anti-corruption policy with anti-corruption corporate and statutory regulations enacted in the countries of its presence.

\section{Statement of the problem}

In order to comprehend the content of the measures excluding liability for involvement in corruption, it is necessary to refer to anti-corruption compliance practices of foreign and multinational companies that enable impunity under the UK Bribery Act 2010. This is the area where the corporate regulations established to combat corruption and fraud and to ensure a due care policy in business are valid. They are of special significance.

Feasibility of criminal prosecution of a company stimulates development of early preventive measures due to the fact that reputation costs may arise after the anti-corruption investigation has been initiated, regardless of its results. Given that indirect corruption risks are highly probable, it is necessary to propose such measures that enable to exclude charges with organization's omission to act in order to prevent the corrupt activity of its contractors.

There are a few practical examples of such measures in domestic business practice. They can be exemplified only by representative offices of the foreign companies operating in Russia or by joint ventures. Thus, it is useful to describe the experience of foreign companies conducting their foreign economic activity worldwide and implementing preventing measures of their exposure to extraterritorial anti-corruption regulations. This experience is diverse. Taking into account different legal mentality and specific corporate principles of companies, we highlight only common principles.

\section{Discussion}

Basic criteria enabling to identify threats to company's assets, which can be posed by contractors, are achieved through the inspection of:

- tax incidents in different jurisdictions;

- compliance with loan and payment policy;

- unfair business practices;

- receivables management; 
- violations of anti-money laundering and terrorist financing legislation;

- affiliation with organizations that are legally sanctioned for committed violations;

- practice of intellectual property management referring to compliance with license agreements and patents;

- completeness of the content of corporate norms regulating resolution of anti-corruption ethical dilemmas (receiving, giving, and exchanging business gifts; rules of remuneration, hospitality expenditures, commissions, charity, and sponsorship).

Special anti-corruption set of criteria may include indicators of proposals that can arise during the joint activity:

- on using transit accounts in transactions;

- on particular agents and contractors ensuring (assisting) implementation of joint business processes (financial institutions, insurance organizations, as well as consulting and auditing companies);

- on transferring wire payments (or their parts) into cash payments.

One of the anti-corruption components of a Due Diligence checklist, including procedures for getting a true and fair view of Due Diligence of a company, can be the analysis and assessment of principals and rules of contractual and legal activities, as well as record keeping and reporting. Positive indicators will be the following terms and conditions about:

- disclosure of data about beneficiaries, contractors, dealers, distributors, suppliers in contracts;

- long-term contracts with a price formula;

- information about incidents of a company in foreign jurisdictions that are of legal and economic importance;

- occasional joint audit of contract performance;

- copyright protection and civil circulation of intellectual property items;

- anti-corruption clause providing for termination of a contract should the facts of corruption in a company be established.

When giving examples of provisions of contract that combat loss of assets, standard form contracts, serving this purpose, shall be mentioned. They not only ensure predominance of rights and interests of the party that offers a draft of a contract first. Availability of standard form contracts in legal activities of a company not only reflects the image of its transparency and responsibility, but it also has a practical result. The party that is offered to make such contract is automatically involved in its contractor's policy and creates its positive dependence, replicating corporate regulations of impeccable business with a snowball effect.

Quite often anti-corruption policy of companies conducting their economic activity in foreign jurisdiction provides direct references to the requirements of the legislation and law-enforcement resources of the country of their presence. Thus, they show respect to them and willingness to imperatively comply with them.

There is also another approach, which is expressed by preparation of "The Handout on Minimizing Company's Corruption Risks Outside the Russian Federation". The Handout includes the review of anti-corruption measures in foreign countries where a company operates. This Handout is universal. In terms of a legal aspect, it reflects the principles of anti-corruption policy of a company; in terms of a procedural and institutional aspect, it standardizes its anti-corruption regulations and aligns them in compliance with statutory requirements of the countries of the business presence; in terms of the methodology, it is a specialized illustrated operational handbook for anti-corruption enlightenment; strategically, it provides the early prevention of corruption risks and liability for it. The Handout may include detailed instructions on the actions of a company and its employees in case of extortion, provocation of bribery, inducing to illegal fraudulent actions, or occurrence of other corruption risks.

The approach of assimilation and sharing effective anti-corruption measures, as well as development of their industry standards will be prospective for the companies conducting 
their foreign economic activity or implementing joint investment and production projects. It is needless to say that this approach shall be implemented, when reasonably complying with the legal foundations and principles of the national legislation. Modern trends of security policy of multinational companies that focus on producing goods, carrying out works, or providing services are being implemented in this direction. This policy is formed not only by development, but also by promotion of the industry anti-corruption standards and procedures among partners and contractors. Pharmaceutical, extractive, energy, and mechanical engineering industries show the signs of these trends. It is essential for many companies not only to declare and promote anti-corruption regulations within their consortium, but also to develop and introduce the methods of:

- identification of corruption risks typical for the industry;

- industry specification of internal control and audit;

- specific features of settlement of the conflict of interests;

- development and introduction of methods of specialized examinations.

Harmonization of the anti-corruption policy of Russian companies operating abroad with corruption prevention principles common for the business world can be provided by means of compliance with the Russian National Standard "Guidance on Social Responsibility" (GOST R ISO 26000:2012). It is identical with the international standard (ISO 26000:2010 "Guidance on Social Responsibility"). According to the Standard in order to combat corruption, a company must:

- identify corruption risks, introduce and implement practices combating corruption;

- carry out work aimed at eradication of corruption among company's employees;

- increase awareness of corruption prevention among company's employees, representatives, contractors, and suppliers;

- pay company's employees and representatives only for legal services.
The aforementioned positions of corporate social responsibility of a company shall be connected with the regulations of its anti-corruption policy and shall be stipulated in the code of ethics for employees and other regulatory acts of an organization. The positions can be implemented differently in practice. Companies conducting their foreign activity should be recommended either to initiate, or to actively participate in:

- development of codes of fair industry trade practice excluding use of illegal ways of providing benefits (profit, advantages) in order to ensure competition;

- adopting mutual declarations on exchanging business gifts and managing the conflict of interests;

- establishing industry "Speak Up" services;

- joint projects for training employees of partner companies how to comply with anti-corruption standards in order to achieve their unification;

- creation of industry indicators of corruption perception, which results are used in order to provide investment guarantees, contract obligations;

- determination of typical industry alarm indicators of predicate corruption delicts (mixing personal and corporate funds; frequent change of beneficiaries, keen interest to terms of cancellation of a contract, unreasonable advancement of expenses).

\section{Conclusion}

Activities and development work of a company aimed at providing anti-corruption measures to protect its assets can be implemented in different jurisdictions or within international unions (the Eurasian Economic Union, BRICS, etc.). Their implementation will not only prove openness (transparency) of organizations, but it will also let minimize their reputation costs in cases of detection of corruption and criminal prosecution for it.

The practice of application of foreign anti-corruption legislation includes examples of exclusion of legal liability of a company taking all possible measures to prevent acts of corrup- 
tion, even if its employees' guilt in committing them is proven in court. In particular, there are such regulations in the Commercial Code of the French Republic (Art. L464-2); in the Sentencing Guidelines of the United States Sentencing Commission.

In the meantime, more often it is comprehensive implementation of the aforementioned preventive measures that combats occurrence of risks of liability or damage, as well as risks to company's reputation.
In the absence of common approaches to organizational, methodological, regulatory support, as well as application of anti-corruption measures for protection of companies abroad, the aforementioned analysis of the practices in this area is of intended use. It is proposed to be considered in the methodological positions of the prospective development of a unified strategy for the prevention of corruption risks for domestic companies operating abroad.

\section{References}

Convention on Combating Bribery of Foreign Public Officials in International Business Transactions and related documents (2011). Available at: www.oecd.org/daf/anti-bribery/ConvCombatBribery ENG.pdf

Commentaries on the Convention on Combating Bribery of Foreign Public Officials in International Business Transactions (2011). Available at: www.oecd.org/daf/anti-bribery/ConvCombatBribery ENG.pdf

Dodd-Frank Wall Street Reform and Consumer Protection Act (2010). In PUBLIC LAW 111-203JULY 21, 2010. Available at: www.gpo.gov/fdsys/pkg/PLAW-111publ203/pdf/PLAW-111publ203.pdf

Foreign Corrupt Practices Act 1977. In PL 95-213, Title 1; 91 Stat 1494, Dec 19, 1977.

Guidance about procedures which relevant commercial organizations can put into place to prevent persons associated with them from bribing. Ministry of Justice. March 2011. In The Bribery Act 2010. Available at: http://www.justice.gov.uk/downloads/legislation/bribery-act-2010-guidance.pdf

Ivanov, E.A. (2015). Anti-Corruption compliance in BRICS countries. Publishing house Yurisprudencia. Moscow.

Joint prosecution guidance of the Director of the Serious Fraud Office and the Director of Public Prosecutions of 2011. In Serious Fraud Office. Available at: www.sfo.gov.uk

International Anti-Bribery and Fair Competition Act of 1988(1988).S. 2375: Pub L 105-366.

Nicholls, Colin QC. (2011). Daniel Tim, Bacarese Alan, Hatchard John. Corruption and misuse of public office. NY: Oxford University Press.

Teichmann, C. (2014). Compliance. Rechtliche Grundlagen fur Studium und Unternehmenspraxis. Munchen: C.H. BeckoHG.

UK Bribery Act of 2010 (2010). Available at: http://www.legislation.gov.uk/ukpga/2010/23/contents 


\title{
Антикоррупционная защита российских компаний в зарубежных юрисдикциях
}

\author{
B.В.Астанин \\ Банк России \\ Российская Федерачия, Москва
}

\begin{abstract}
Аннотация. Статья посвящена существующим проблемам и перспективным задачам предупреждения коррупционных рисков и мошеннических угроз, с которыми могут столкнуться отечественные публичные организации, ведущие внешнеэкономическую деятельность в странах своего присутствия. Глобализация антикоррупционных стандартов правил делового поведения, предъявляемых бизнес-структурам во всем мире, обусловлена трансграничным характером действия законов ряда государств англосаксонской правовой системы, а также Конвенции ОЭСР по борьбе с подкупом иностранных должностных лиц при осуществлении внешнеэкономической деятельности. Данные обстоятельства требуют актуализации задач антикоррупционной политики каждой публичной компании, вне зависимости от страны ее принадлежности, организационноправовой формы и вида собственности. Большинство бизнес-организаций в мире разрабатывают собственные тактические превентивные меры против коррупции за рубежом. Содержание этих мер различно. В условиях отсутствия единства подходов к организационному, методическому, нормативному обеспечению, а также правовому регулированию и применению таких мер в статье представлены результаты мониторинга практик национальных и транснациональных компаний по профилактике коррупционных рисков, способных возникнуть при взаимодействии с иностранными контрагентами. Полученные результаты мониторинга предлагается рассматривать в методологических позициях перспективной разработки единой стратегии превенции коррупционных рисков для отечественных компаний, ведущих свою деятельность за рубежом.
\end{abstract}

Ключевые слова: коррупция, профилактика, внешнеэкономическая деятельность, Due Diligence, компании, внутренний контроль и аудит, англосаксонское право, бизнес, этические дилеммы.

Научная специальность: 12.00.00 - юридические науки. 